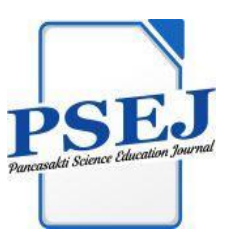

Pancasakti Science Education Journal

PSEJ Volume 4 Nomor 2, Oktober 2019, (Hal. 64 -69)

http://scienceeduiournal.org/index.php/PSEJ/issue/view/7 doi: $10.24905 /$ psej.v4i2. 1266

Submitted: 10/05/2019, Accepted: 30/10/2019, Published: 31/10/2019

\title{
Pengembangan Media Pembelajaran Interaktif dengan Pendekatan Saintifik Berbasis Power Point Text Macro pada Materi Kinematika
}

\author{
Fitri Fajriani ${ }^{1}$, Edi Supriana ${ }^{2}$, Sentot Khusairi ${ }^{3}$ \\ Universitas Negeri Malang, Indonesia \\ Korespondensi. E-mail: fitri.fairiani@um.ac.id
}

\begin{abstract}
Abstrak
Pengembangan media pembelajaran interaktif dengan pendekatan saintifik berbasis power pont text macro pada materi kinematika dilaksanakan untuk mengembangkan media pembelajaran interaktif yang valid dan efektif agar dapat digunakan dalam proses pembelajaran, sehingga mampu membantu siswa untuk memperkuat konsep fisika yang mereka punya dan mengurangi miskonsepsi. Penelitian ini menggunakan metode penelitian dan pengembangan metode ADDIE (Analysis, Design, Development, Implementation, dan Evaluation). Pengumpulan data dilakukan dengan pengisian kuisioner. Data yang diperoleh berupa data kuantitatif dan kualitatif. Produk pengembangan ini melalui dua tahap pengujian yaitu validitas produk dan uji coba terbatas. Hasil daripada analisis data produk ini telah dinyatakan valid dengan nilai rata-rata kevalidan media sebesar $79,45 \%$ dan hasil uji coba terbatas sebesar $80,02 \%$ sehingga dapat digunakan dalam proses pembelajaran.
\end{abstract}

Kata Kunci: Media Pembelajaran Interaktif; Kinematika

\section{Development of Interactive Learning Media with Power Point Text Macro Approach to Science in Kinematic Material}

\begin{abstract}
Development of interactive learning media with scientific approach based on power point text macro in kinematic research was conducted to develop interactive learning media that can be valid and effectively used in the learning process in order to help students to strengthen their physics conceptual ability and decreasing misconception. This research used research and development ADDIE (analiysis, design, development, implementation, and evaluation) model. Questionnaire was used to do the data collection. The obtained data was in the form of quantitative and qualitative data. The product of this development went through two stages of testing which are the validity of the product and limited trial. The results of this data analysis is valid with the average value of the validity 79,45\% and limited trial percentage $80,02 \%$, in other words this interactive media is valid enough can be used in daily learning activity.
\end{abstract}

Keywords: : Interactive learning media; Kinematics 


\section{PENDAHULUAN}

Perkembangan teknologi informasi dan komunikasi di abad ke-21 saat ini sangatlah pesat di semua bidang termasuk bidang pendidikan. Kurikulum 2013 menuntut pembelajaran berbasis penggunaan Information Communication and Technology (ICT). Dalam Peraturan Pemerintah Nomor 65 tahun 2013 tentang Standar Proses yang menyatakan bahwa salah satu prinsip pembelajaran dalam kurikulum 2013 adalah adanya pemanfaatan dan penggunaan ICT untuk meningkatkan efisiensi dan efektivitas pembelajaran. Efektivitas dan efisiensi proses pembelajaran dapat meningkat melalui penerapan multimedia yang interaktif dalam proses pembelajaran. Dalam kurikulum 2013 juga dijelaskan bahwa salah satu pendekatan yang digunakan adalah pendekatan saintifik (scientific approach). Penelitian yang telah dilakukan oleh Siswanto (2014) tentang penerapan model pembelajaran pembangkit argumen menggunakan pendekatan saintifik mendapatkan hasil bahwa pendekatan saintifik secara signifikan mampu meningkatkan kemampuan kognitif dan keaktifan siswa dalam berargumentasi, hal ini akan berpengaruh kepada penguasaan konsep siswa sehingga siswa tidak akan mengalami miskonsepsi.

Berbagai kesulitan yang dialami siswa bisa dikarenakan adanya miskonsepsi sesuai pernyataan dari Docktor dan Mestre (2014) yang menyatakan bila miskonsepsi terjadi karena adanya teori naif yang dibangun oleh siswa, adanya pengetahuan yang terpotongpotong serta pengelompokkan pengetahuan ke dalam kategori yang tidak tepat. Sehingga pada pembelajaran fisika di sekolah, penting untuk memastikan bahwa siswa menguasai konsep sains yang sedang dipelajari (NAEP, 2005). Hal ini didukung oleh pernyataan Chang et al (2010) bahwa penguasaan konsep siswa selalu dianggap sebagai salah satu isu penelitian yang penting untuk mengevaluasi pembelajaran sains karena mempengaruhi seberapa efektif siswa bisa menyelesaikan suatu permasalahan.
Penggunaan multimedia pada pokok bahasan kinematika dengan pendekatan saintifik dan dipadukan dengan media pembelajaran interaktif berbasis komputer bisa dijadikan solusi penerapan model pembelajaran yang tepat untuk menghasilkan pembelajaran yang diharapkan. Hampir seluruh pendidik juga setuju bahwa pembelajaran sains harus berpindah dari sistem yang menunjukkan bahwa sains secara umum hanya tentang informasi faktual dan komputasi menjadi penekanan pada penguasaan konsep dan kemampuan proses logika (Saleh, 2011). Istilah pemaham konsep dianalisa untuk menentukan bagaimana pendidik bisa membatu siswa mendapatkan penguasaan dalam kurikulum berbasis konsep (Mills, 2016).

Tujuan yang ingin dicapai dari penelitian ini adalah mengembangkan media pembelajaran interaktif dengan pendekatan saintifik yang bisa membantu siswa untuk lebih menguasai konsep fisika dengan baik tanpa adanya miskonsepsi dan mengetahui tingkat kevalidan produk yang telah dikembangkan.

\section{METODE}

Penelitian ini menggunakan metode penelitian dan pengembangan menurut ADDIE yang terdiri atas 5 langkah yaitu analysis (tahap analisis), design (tahap desain), development (tahap pengembangan), implementation (tahap implementasi), dan evaluation (tahap evaluasi). Tahap analisis adalah tahap peneliti mengumpulkan informasi tentang kebutuhan media pembelajaran interaktif yang dibutuhkan. Tahap desain adalah tahap peneliti merencanakan dan membuat media pembelajaran interaktif, tahap development adalah peneliti mengkonsultasikan media pembelajaran yang telah dibuat kepada para validator untuk mendapatkan masukan yang dibutuhkan. Tahap implementasi adalah uji coba terbatas yang dilakukan terhadap sekelompok mahasiswa di Universitas Negeri Malang, hasil daripada uji coba terbatas tersebut yaitu dengan pengisian angket 
kuisioner. Terakhir tahap evaluasi dimana peneliti melakukan perbaikan atas hasil analisis data kuantitatif dan kualitatif dari hasil uji coba terbatas.

Data yang diperoleh berupa data kuantitatif dan data kualitatif. Data kuantitatif dianalisis dengan teknik perhitungan persentase untuk mencari tahu tingkat kevalidan dan bahan ajar yang dikembangkan. Sedangkan data kualitatif digunakan sebagai pertimbangan revisi bahan ajar. Produk pengembangan ini melalui dua tahap pengujian yaitu validitas produk dan uji coba terbatas. Uji validitas dilakukan kepada dua guru fisika, sedangkan uji coba terbatas dilakukan di Universitas Negeri Malang. Subjek uji coba terbatas yaitu mahasiswa jurusan fisika semester 2 yang berjumlah 20 orang.

\section{HASIL DAN PEMBAHASAN}

Hasil dari penelitian dan pengembangan ini berupa media pembelajaran interaktif fisika pada materi kinematika. Media pembelajaran interaktif ini dikembangkan dengan bantuan Power Point Text Macro dan produk akhir pengembangan media pembelajaran ini berupa file dengan ekstensi ".pptm" sehingga dalam penggunaannya terlebih dahulu mengisntall Microsoft Office Power Point. Selanjutnya semua file media pembelajaran interaktif yang telah valid dikemas dalam satu CD (Compact Disk) dan dilengkapi dengan petunjuk penggunaan dalam format .pptm. Materi yang disediakan didalam media pembelajaran interaktif ini adalah materi kinematika yang dilengkapi dengan teks, gambar, suara, animasi, dan video. Konten dalam media tersebut disajikan dengan pendekatan saintifik sehingga materi dalam media ini memiliki lima tahapan yaitu goal (tujuan), check your knowledge (cek pengetahuan awal), explanation (penjelasan), get your feedback (mendapat umpan balik), dan evaluation test (tes evaluasi).

Adapun hasil analisis data kuantitatif untuk kategori kevalidan dari media interaktif yang dikembangkan disajikan dalam Tabel 1.

Tabel 1. Kategori Kevalidan dan Kelayakan Produk

\begin{tabular}{c|c|c}
\hline No & Kriteria Kevalidan & Tingkat Kevalidan \\
\hline 1 & $85,01 \%-100,00 \%$ & Valid, bisa digunakan tanpa revisi \\
2 & $70,01 \%-85,00 \%$ & Cukup valid, bisa digunakan namum perlu \\
sedikit revisi.
\end{tabular}

Adaptasi dari Akbar (2013)

Analisis data hasil validasi media pembelajaran interaktif diperoleh dari rata-rata persentase dua validator, yaitu dua guru Fisika. Data validasi kevalidan media memiliki beberapa aspek yaitu kelayakan isi dan penyajian, kelayakan Bahasa, penilaian kontekstual, dan kelayakan kegrafikan. Data kuantitatif hasil uji kevalidan media oleh masing-masing validator, dihitung dengan menggunakan teknik persentase yang secara umum hasil uji kevalidan media dapat dilihat pada tabel 3. Sedangkan untuk setiap aspek dinilai berdasarkan beberapa kriteria dipaparkan pada Tabel 2. 
Pancasakti Science Education Journal, 4 (2), Oktober 2019- (67)

Fitri Fajriani, Edi Supriana, Sentot Khusairi

Tabel 2. Rekapitulasi Hasil Validasi Setiap Aspek Media Interaktif

\begin{tabular}{ccccc}
\hline Aspek Validasi & \multicolumn{2}{c}{ Validator } & Rata-rata & Kategori Validitas \\
\cline { 2 - 3 } & Guru 1 (\%) & Guru 2(\%) & & \\
\hline Kelayakan Isi dan Penyajian & 87,5 & 81,3 & 84,4 & \\
\hline Kelayakan Bahasa & 77,8 & 80,6 & 79,2 & Cukup Valid \\
\hline Penilaian Kontekstual & 75,0 & 77,8 & 76,4 & Cukup Valid \\
\hline Kelayakan Kegrafikan & 75,0 & 80,8 & 77,9 & Cukup Valid \\
\hline
\end{tabular}

Tabel 3. Hasil Analisis Data Keseluruhan Validasi Media Interaktif

\begin{tabular}{ccccc}
\hline Aspek Validasi & \multicolumn{2}{c}{ Validator } & Rata-rata & Kategori Validitas \\
\cline { 2 - 3 } & Guru 1(\%) & Guru 2(\%) & & \\
& & & $(\%)$ & \\
\hline Validitas Keseluruhan & 78,8 & 80,1 & 79.45 & Cukup Valid \\
\hline
\end{tabular}

Berdasarkan kriteria uji kevalidan media maka media pembelajaran interaktif pada materi kinematika dengan pendekatan saintifik ini mencapai rata-rata $79,45 \%$ yang mana masuk dalam kategori cukup valid. Hal ini menunjukkan bahwa media interaktif yang dikembangkan sudah dapat digunakan sebagai salah satu media pembelajaran dalam proses belajar mengajar secara umum di kelas dan sudah dapat untuk diuji coba untuk dipergunakan lebih luas. Untuk lebih menyempurnakan lagi dapat dilakukan revisi berdasarkan komentar dan saran yang diberikan oleh validator. Hasil analisis data kuantitatif untuk uji coba terbatas media interaktif tersaji pada Tabel 4.

Tabel 4. Hasil analisis data kuantitatif siswa

\begin{tabular}{ccc}
\hline Aspek Uji Coba Terbatas & Rata-rata (\%) & Kategori Validitas \\
\hline Uji Coba Terbatas Keseluruhan & 80,02 & Cukup Valid \\
\hline
\end{tabular}

Berdasarkan analisis data kuantitatif hasil uji coba keterbacaan media pembelajaran diperoleh hasil persentase sebesar 80,02\% sehingga kriteria yang di dapat termasuk dalam kategori cukup valid. Dari hasil tersebut dapat disimpulkan bahwa media pembelajaran interaktif ini sudah efektif digunakan dalam pembelajaran.

Hasil uji kevalidan dan uji coba terbatas menunjukkan kategori cukup valid, meskipun demikian revisi masih perlu dilakukan berdasarkan komentar dan saran yang telah diberikan validator dan mahasiswa. Revisi produk bertujuan untuk memperbaiki produk yang telah dikembangkan. Revisi dilakukan bedasarkan hasil uji kevalidan oleh validator serta hasil uji coba terbatas oleh mahasiswa jurusan fisika Universitas Negeri Malang. Hasil revisi produk dapat dilihat pada Tabel 5.

Tabel 5. Revisi Produk

\begin{tabular}{|c|c|c|c|}
\hline No & Media Sebelum Revisi & Saran & Media Setelah Revisi \\
\hline 1 & 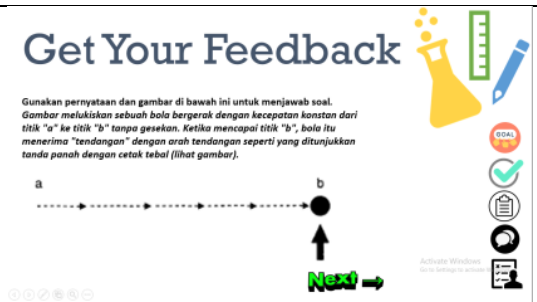 & $\begin{array}{l}\text { Format } \\
\text { gambar dan } \\
\text { petunjuk soal } \\
\text { kurang jelas. }\end{array}$ & 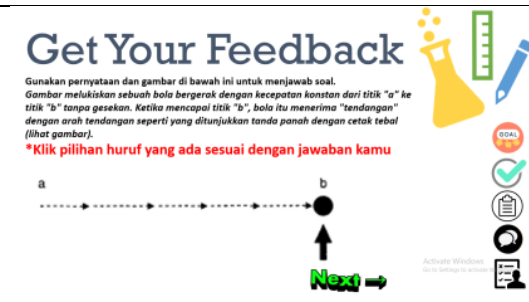 \\
\hline
\end{tabular}


Pancasakti Science Education Journal, 4 (2), Oktober 2019- (68)

Fitri Fajriani, Edi Supriana, Sentot Khusairi

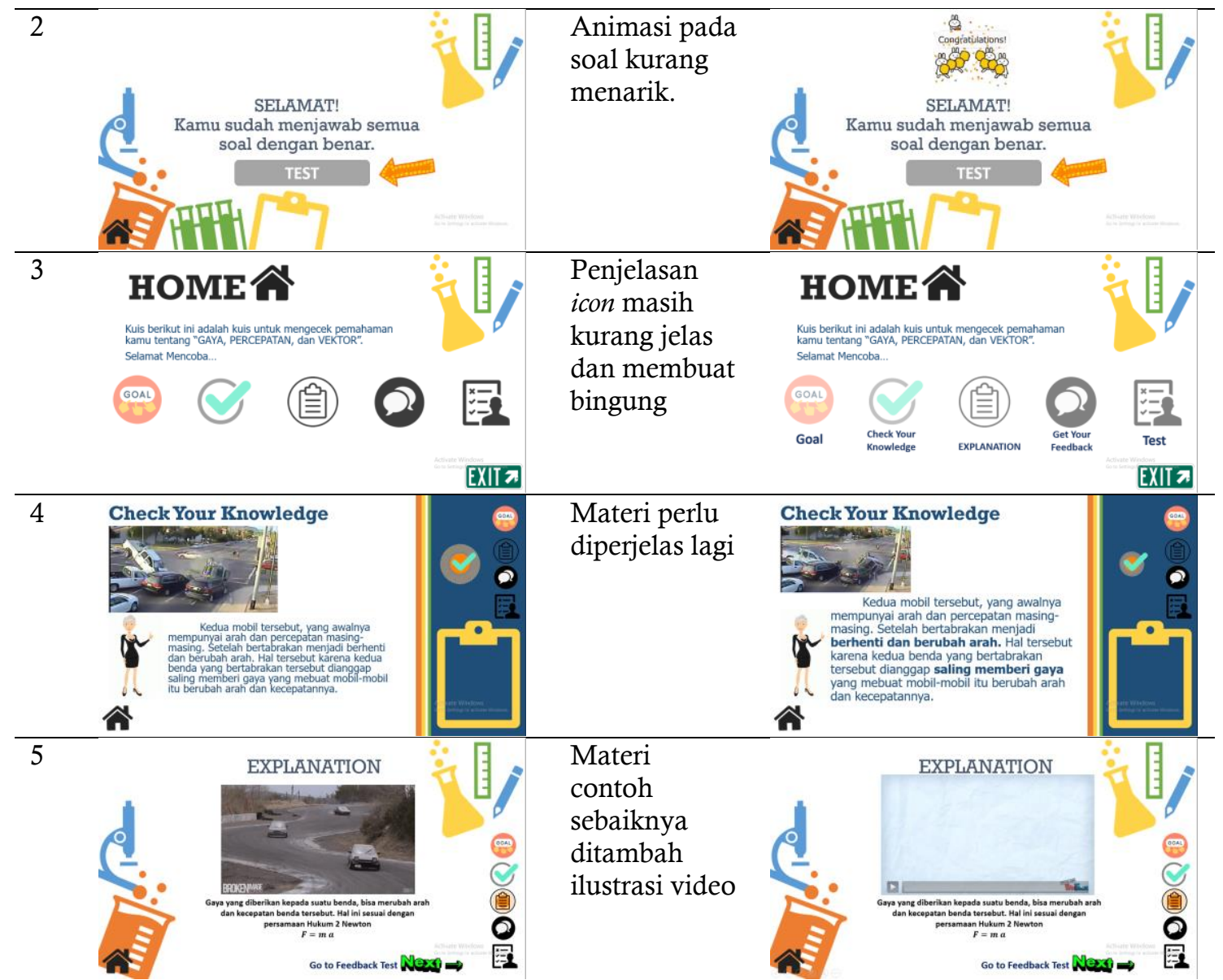

\section{SIMPULAN}

Produk media pembelajaran interaktif yang telah dibuat ini sudah diuji kevalidan dan kepraktisannya. Uji kevalidan dilakukan oleh dua validator yakni dua guru fisika. Berdasarkan analisis uji kevalidan media dapat diketahui bahwa media pembelajaran ini dapat dinyatakan valid dengan persentase $79,45 \%$ masuk dalam kategori cukup valid dan terdapat beberapa revisi di dalamnya. Sedangkan uji coba terbatas pada mahasiswa jurusan fisika Universitas Negeri Malang juga dapat dinyatakan cukup valid dengan persentase $80,02 \%$. Secara umum bisa diketahui bahwa secara keseluruhan media pembelajaran interaktif pada materi kinematika ini disajikan dengan menarik dan dapat mendukung proses belajar siswa. Hal ini dibuktikan dengan komentar yang diberikan siswa pada angket yang telah mereka isi. Saran untuk keperluan pengembangan lebih lanjut yang dapat diberikan adalah sebagai berikut. Pertama, melakukan penelitian dan pengembangan lebih lanjut terhadap media pembelajaran interaktif fisika dengan pendekatan saintifik pada materi lain yang banyak terdapat kesulitan siswa. Kedua, soal yang terdapat dalam media pembelajaran interaktif sebaiknya dikembangkan soal yang bertingkat dari level mudah, sedang, dan sulit. Ketiga, menguji efektivitas dari media yang telah dikembangkan.

\section{DAFTAR PUSTAKA}

Akbar, S. 2013. Instrumen Perangkat Pembelajaran. Bandung: PT. Remaja Rosdakarya.

Chang Chun-Yen, Yeh Ting-Kuang \& James P. Barufaldi. 2010. The Positive and Negative Effects of Science Concept Tests on Student Conceptual Understanding. 
Pancasakti Science Education Journal, 4 (2), Oktober 2019- (69)

Fitri Fajriani, Edi Supriana, Sentot Khusairi

International Journal of Science

Education, 32:2, p265-282.

Docktor, J. L and Mestre, J. P. 2014. Sythesis of dicipline-based education research in physics. Physical Review Special Topic Physics Education Research, 10, 020119.

Mills, S. (2016). Conceptual Understanding: A Concept Analysis.The Qualitative Report, 21(3), p546-557.

NAEP (National assessment of Educational Progress). 2005. Science Conceptual Understanding. Retrieved from http://nces.ed.gov/nationsreportcard/

Saleh, Salmiza. 2011. The Level of B.Sc.Ed Students' Conceptual Understanding of Newtonian Physics. International Journal of Academic Research in Business and Social Sciences. Vol. 1, No. 3 ISSN: 22226990.

Siswanto. 2014. Penerapan Model Pembelajaran Pembangkit Argumen Menggunakan Metode Saintifik Untuk Meningkatkan Kemampuan Kognitif Dalam Keterampilan Berargumentasi Siswa. Jurnal Pendidikan Fisika Indonesia. 10 (2): 104-116 